\title{
The vultures at the crossroads of biodiversity, politics, tourism, the environment, and agriculture
}

\author{
Jean-Pierre Choisy
}

Ex Chargé de mission au PNR Vercors (1993-2011); LPO (Birdlife France) Mission Rapaces Vulture Specialist Group of the IUCN Species Survival Commission jpchoisy@gmail.com

"This text was first published in French in Le Courrier de l'Environnement de I'INRA n61, pp. 69-83 (2011). Permission granted by Le Courrier, 2013.

The general extermination of the vultures from the Old World (Orabi 2011) mostly occurred in the $20^{\text {th }}$ Century, slightly earlier in Europe, especially north of the three major Mediterranean peninsulas. More recently in Africa and Asia, vultures are under threat. The ranges of various species have been reduced to isolated remnants and their populations to have declined dramatically, with few exceptions.

Hunting and the systematic destruction of birds of prey, especially in
Europe where it was formerly an obsessive activity for several generations, had catastrophic effects on raptors. Essentially, because the key parameter for demographic stability of populations of large species is low adult mortality, the effects of direct destruction were sufficient to eliminate the Bearded Vulture Gypaetus barbatus in the Alps and other parts of Europe outside Crete.

Vulture populations have been drastically reduced by poisoning, usually accidental or secondary, but catastrophic 
nonetheless, by consuming poison baits for carnivores (sometimes wild boar or the carcasses of these) (Orabi 2011), or by consuming carcasses of cattle treated with the anti-inflammatory drug diclofenac in South Asia (Prakash et al. 2002, 2005, 2007; Green et al. 2006; Swan et al. 2006, Cuthbert et al. 2007).

Vultures have also been affected by loss of food. Over thousands of years domestic livestock, by effectively replacing wild ungulate populations, has provided an increasing proportion of the carcasses consumed by vultures.

Two countries in Europe are characterised by healthy populations of vultures. Spain, first, has been the bastion of vultures in Europe since as early as the 1970s (Cramp et al. 1980) thanks to the continued use of scavengers as the primary means of disposing of livestock carcasses. Effective protection is leading to the Bearded Vulture, Griffon Vulture Gyps fulvus and Cinereous Vulture Aegypius monachus experiencing remarkable revivals. France, once almost devoid of vultures, pioneered the reintroduction of vultures since the first attempts of the 1970s (Terrasse 2001; Terrasse et al. 2004) and has achieved remarkable success (Table 1 ). 
Table 1: Number of pairs of vultures in continental France

\begin{tabular}{|l|l|l|l|l|l|}
\hline & Year & Gyps fulvus & $\begin{array}{l}\text { Aegypius } \\
\text { monachus }\end{array}$ & peophron & Gypaetus \\
\hline Pyrénées & 1970 & 50 & 0 & $35^{*}$ & 10 \\
\hline & 2011 & $\sim 500$ & 0 & $65-69$ & 35 \\
\hline Alps, Provence, & 1970 & 0 & 0 & $11^{*}$ & 0 \\
\hline massif Central & & & & & 8 \\
\hline
\end{tabular}

Figures in italics: Populations founded by reintroduced vultures in the Pyrénées. ${ }^{*} N$.

percnopterus minimums from 1982

The restoration of the vultures in France

has been possible by local conservation

efforts and, except for the Bearded

Vulture, the restoration natural carcass

availability. Examining the benefits and

consequences of vulture feeding stations,

which now have a regulatory basis in the

European Union, is the object of the present work.
Vultures: Natural Knackers [undertakers]

The Griffon Vulture opens the carcasses of ungulates and feeds on viscera and muscle. The Cinereous Vulture cuts and eats the tougher tissues (skin, tendons, cartilage, etc.). The Egyptian Vulture Neophron percnopterus with its narrow 
beak pecks smaller pieces of meat between the ribs, inside the skull and on parts left behind by the larger vultures, including contents of the rumen. Finally, the Bearded Vulture Gypaetus barbatus consumes the skeleton. When it is complete, this guild of carrion birds is an effective system for the removal of carcasses (Chassagne 1998). The system is complemented by partial scavengers such as Sea Eagle Haliaeetus albicilla, kites and Corvids.

In the non-breeding season, a vulture needs 450 to $500 \mathrm{~g}$ of food per day, which increases by $38 \%$ for five months per year during the breeding season (Morio 2006). The food requirements for a population consisting of approximately $50 \%$ breeders (Sarrazin, personal communication) is therefore approximately $800 \mathrm{~kg}$ of food per breeding pair per year. This amount is supplied with an actual 1.5 tonnes of carcasses, of which $53 \%$ is consumable by species (Morio 2006), the remainder being available for other vultures and small scavengers (see also Choisy 2004b).

\section{Policies concerned by vultures}

The contribution of vultures to faunal diversity greatly exceeds the addition to species richness, owing to their taxonomic originality and ecological role in the functioning of communities (Choisy 2003). The conservation and restoration of their habitats and their populations are important biodiversity goals at local, regional, national and international levels. Other sectors are affected positively by the presence of these birds, as more and more benefits are taken into account, including financial benefits.

\section{Tourism}

Where they are present, vultures are among the most important species in 
encouraging nature tourism: $85 \%$ of

visitors to Gamla Reserve (Israel) come to see vultures (Becker et al. 2010). In France, in small townships in the Alps with only 5.5 inhabitants per square kilometre, 15 - 20000 people per year visit the home of vultures in Rémuzat, which was the first municipality where vultures were released in the French Alps, in 1996. Only seven years later during a European seminar, its Mayor (a retired banker) pointed out the local economic impact from the return of the vultures (Choisy 2004). In the Causses (massif Central), in 1995 the net profit from local tourism due to the presence of vultures was already 4.4 million francs, and the profit from the image of vultures as a tool of advertising and promotion was, perhaps, even more important (Quillard 1995). Case studies on this subject remain still too rare, in Europe as elsewhere.

\section{Agriculture}

Carcasses of deceased livestock can either be collected from farms and sent to a large vulture feeding station, or eaten by vultures at small feeding sites operated by farmers, or left in the in the fields. In any case, the time and work savings are valued by those who benefit, especially in mountainous areas: the transport to disposal centres of carcasses in these areas is longer and more difficult than elsewhere. In 2010, vultures in France saved $€ 430000$ of public funds that would have been used for carcass disposal (Orabi 2011). The environmental benefits, including health, also apply to agricultural policies.

\section{Environment}

Beyond the elimination of carcases, the role of vultures in health has been the subject of veterinary research in France 
for more than twenty years (Briquet 1990, Chassagne 1998). The quicklime used to decompose buried carcasses has a strong action on liquids produced by the carcass, but a limited effect on the carcasses themselves. Burial does not prevent the sporulation of pathogenic bacteria, which can survive many years, and may be brought to the surface by earthworms. Vultures, on the other hand, constitute an epidemiological dead-end: The gut of vultures destroys all the microorganisms that could survive in carcasses, apart from a few very resistant spores (Chassagne 1998). The consumption of an infected carcass almost always takes place prior to sporulation. Bacteria are killed by the extreme acidity of the digestive environment of these birds $(\mathrm{pH}$ 1 to 1.5 and even less than 1 in the Bearded Vulture). The action of vultures is considered safe and particularly beneficial in low and medium mountain areas (Chassange 1998). The benefits are even more so in the case of high mountains, where the proportion of undiscovered dead livestock is higher. The carcass disposal benefits of vultures are the same for wild ungulates, particularly in the mountains where their abundance (and therefore carcass abundance) is higher than elsewhere.

The abandonment of livestock carcasses is common where access by motor vehicle is difficult. Because it is illegal to abandon carcasses, their presence in hard to reach areas can lead to carcasses being concealed in narrow ravines that are inaccessible to scavengers. As a result, drainage lines and water supplies can be polluted. The collection of carcasses to vulture feeding stations, and easier still, the reintroduction vultures leads to a significant decrease in these irregularities and neutralizes those carcasses that remain: the carcasses are now left in the places accessible to the vultures who 
consume them quickly (see also Choisy 2004b).

\section{Reduction of emissions of $\mathrm{CO}_{2}$}

If the corpses of livestock that died in 2010 and were consumed by vultures had been disposed of by industry, between 675 and 780 tonnes of additional $\mathrm{CO}_{2}$ would have been emitted, increasing to more than 1000 tonnes if transport emissions are taken into account (Orabi 2011). Based on this, in 2010, the economic benefit of vultures was greater than $€ 10,000$, on the basis of cost per tonne of $\mathrm{CO}_{2}$ at market prices at the beginning of the year, or $€ 13$ tonne $e^{-1}$ (Orabi 2011).

\section{How many vultures?}

In mainland Spain, after decades of action for vultures, the 2008 Census counted 25 075 pairs of vulture $( \pm 1.86 \%$ del Moral 2009), which is one pair per $20 \mathrm{~km}^{2}$.

\section{Spain: a relevant reference?}

This number of vultures in Spain has been challenged as being artificially high, or 'unusual'. However, where livestock has existed for several millennia, why is it considered abnormal that the numbers of vultures reflect the reality of their food supply? It would possibly also be considered abnormal the presence of House Martins Delichon urbica and Black Redstarts Phoenicurus ochruros in areas where the walls of buildings are the substitute for thousands of years of rock faces necessary for their nests.

Nevertheless, it is not without interest to test the validity of the hypothesis: that the size of the Griffon Vulture population in Spain is of a size other than what it would be in a natural situation. If that were the case, there would be possible competition for nests at the expense other rock-nesting raptors. Additionally it is necessary to address discussions about the size of 
wildlife populations in ways other than "zero, one, two, too many", and the example of Spanish vultures may form a valuable reference point for estimating the population sizes in other situations and countries.

\section{Hypothesis test}

The hypothesis above can be applied to quantitative data from 20 years of research in the Serengeti (Tanzania) (Sinclair and Northon-Griffiths 1979; Mundy et al. 1992). Here, populations of Rüppell's Griffon Gyps rueppellii and African White-backed Vulture Gyps africanus feed exclusively on wild ungulates in an area of approximately $25,000 \mathrm{~km}^{2}$ that incorporates $60 \%$ forest and $40 \%$ grassland. The biomass of wild ungulates is $9320 \mathrm{~kg} / \mathrm{km}^{2}$ to supply 6,000 Gyps rueppellii and 24,000 G. africanus. Taking into account differences in average body weight, these 30,000 Gyps vultures are equivalent to approximately
24,000 Gyps fulvus which, overall, is approximately one bird per $\mathrm{km}^{2}$.

In a Spain without human influence, there is nothing to suggest that the proportion of habitat available to vultures would be one order of magnitude lower than it is in the Serengeti taking account of:

- the exclusion of some habitats (e.g. woodlands) due to ecological, soil and climate factors;

- the opening of some woodlands by abiotic factors (avalanches, storms, natural fires, etc.) and biotic factors (ungulate density changes);

- the behaviour of the Griffon Vulture, which is able to forage in semiwoodland habitats.

The proportion of non-breeding vultures in France is approximately 50\% (Sarrazin, personal communication) whilst in Spain it is only 35\% (del Moral 2009). These two figures combined provide an 
estimated range of 80,000 to 100,000 individuals in 2008 in Spain, or one bird per $5-7 \mathrm{~km}^{2}$, five to seven times less than the Serengeti. Reducing the required biomass of wild ungulates by the same proportion represents an estimate of about $1,600 \mathrm{~kg} / \mathrm{km}^{2}$ ( $\left.\pm 17 \%\right)$.

Primary productivity in Spain being far from being five to seven times lower than in the Serengeti. Under the hypothesis, using an average carcass mass of $75 \mathrm{~kg}$ and the average density of wild ungulates, there is perhaps enough food resources in Spain to support as many as $21.3( \pm 17 \%)$ vultures per square kilometre. Without artificial lowering of populations or a reduction in the diversity of species, this is a density which is not implausible.

The assumption that the overall abundance of vultures in Spain would be an order of magnitude different from what it is today with or without action, direct or indirect, of humans is not consistent with these observed facts.

\section{In France and elsewhere: perspectives}

Among the important factors that must be considered for the restoration of vulture populations, only the availability of carcasses is the considered below.

\section{Which regions?}

Almost all French territory suitable for vultures is located in the south. The return of vultures is clearly not possible in regions where the numbers of wild ungulates and/or domestic livestock are much reduced or zero, such as cultivated fields or urban areas. Due to their nesting and feeding requirements the strongholds for vultures will remain in the mountains, high or low, and their wider surroundings, including coastal cliffs. The return of vultures could also be a local 
objective, particularly for species like the Cinereous Vulture, which nests in trees rather than on cliffs. But local scale is not relevant in this regard. Wherever the abundance of livestock, and therefore of carcasses, is seasonal, the presence of the vultures may also be. The summer nonbreeding range of vultures is in full development in the French Alps. Before 1997 there were no vultures, whilst in 2012, more than 1,500 individuals were counted on the roost site of AlpesMaritimes in Haute-Savoie in the pre-
Alps. Roosting is now beginning in the neighbouring Italian Alps and in Western Switzerland.

\section{Griffon Vulture: population restoration}

\section{and induced gains}

Studies by del Moral (2009) and Orabi (2011) have examined the effects carcass consumption by vultures (Table 2). Considering that Orabi (2011) did not take into account carcasses of cattle or wild ungulates, but goats and sheep, it highlights that the values they obtained were a minimum.

Table 2: Effects of different populations of Griffon Vulture Gyps fulvus on the basis of 1000 in mainland France

\begin{tabular}{|l|l|l|l|l|l|l|}
\hline Number of pairs & $\mathbf{1 0 0 0}$ & $\mathbf{3 5 0 0}$ & $\mathbf{5 0 0 0}$ & $\mathbf{7 0 0 0}$ & $\mathbf{1 0 0 0 0}$ & $\mathbf{1 4 0 0 0}$ \\
\hline $\begin{array}{l}\text { Carcasses removed by vultures } \\
\text { (tonnes) }\end{array}$ & 840 & 2940 & 4200 & 5880 & 8400 & 11760 \\
\hline Decrease of $\mathrm{CO}_{2}$ emissions & 1050 & 3675 & 5250 & 7350 & 10500 & 14700 \\
(tonnes) & & & & & & \\
\hline $\begin{array}{l}\text { Costs saving of carcass disposal } \\
\text { (M€) }\end{array}$ & 0.43 & 1.51 & 2.15 & 3.0 & 4.3 & 6.0 \\
\hline \begin{tabular}{l} 
Percentage of France affected* \\
\hline
\end{tabular} & 3.7 & 13 & 19 & 26 & 37 & 52 \\
\hline
\end{tabular}

*The percentage of continental France $\left(540000 \mathrm{~km}^{2}\right)$ affected is calculated from the average density in Spain (del Moral 2009), which is one pair per $20 \mathrm{~km}^{2}$ (author). 
The area taken into account is not homogenous, but an average between suitable and unsuitable habitats in same region. Thus, assuming that the actual area is the part of France centred on the Alps, Pyrénées and massif Central, the area to be taken into account would be the entire PyrénéesAtlantiques, Mid-Pyrénées, LanguedocRoussillon, Provence -Alpes-Cote-of Azur and, almost, the regions Auvergne and Rhône-Alpes. This does not mean that vultures would be present everywhere, any more than is the case in Spain, but the area is a geographic range. On the same basis, estimates are possible in other regions on a pro rata basis if primary productivity is similar.

\section{Cinereous Vulture}

The carcass parts consumed by this species represent about $27 \%$ of the mass not eaten by Griffons. Therefore, the potential value of this species can be more than a quarter of those of the Griffon (see first line of Table 2).

\section{Bearded Vulture}

Although not nesting on trees, this species can also forage in woodland areas. The Bearded Vulture represents a fraction of the mass of consumed food compared to the previous species. However, a smaller body mass and territorial behaviour makes an assessment of the potential value of this species more difficult. From a management perspective, it is irrelevant to set goals: numbers of this species will grow depending on the resources available from the skeletons left by the two previous species. From the point of view of the restoration biodiversity, it should be noted that:

- The area of the Alps is approximately ten times that of the Pyrenees where 
currently more than 140 pairs exist, with this number increasing;

- The Alps are currently more favourable than the Pyrenees because of the presence of Ibex Capra ibex (Hirzel et al. 2004), currently being restored, with already about 50000 individuals in the Alps, of which $20 \%$ are in France;

- The capacity of the Pyrenees will be, in the long term, increased significantly after the reintroduction project of the Iberian ibex Capra pyrenaica. resources neglected by the three other vultures, whilst on the other hand it is much more in competition for food with kites and Corvids.

On the basis of the 2000 pairs counted in Spain in the 1970s (Cramp et al. 1980) and very similar areas of both countries, the number of potential pairs in France could be estimated by the size of the area where the species could be restored: approximately 200 pairs If this fraction is $10 \%$ of the country, 500 pairs if $25 \%$ and approximately 1,000 pairs if 50\%. These are modest estimates, because the population of reference had already declined.

\section{Egyptian Vulture}

France is the only country in Europe where this species is increasing slowly but surely. Estimating the potential inputs of this species from food supply is difficult because on the one hand it can exploit

\section{Management}

Without going into excessive technical details, below are some points that deserve special attention. 
Major feeding stations or numerous small feeding sites?

Benefits

During a reintroduction of Griffon or

Cinereous Vultures, it is necessary to feed using a large feeding station supplied with carcasses collected from farms (Choisy 2004b).

Once a population has begun to increase, a growing proportion of carcasses can be made available to vultures at smaller feeding sites, each being managed by a farmer. This has already played a significant role in the Causses (Massif central), particularly where some farms are located far away from the main feeding stations (Morio 2006). Vultures being able to locate these resources at random is also close to their natural behaviour.

The larger feeding stations seem to favour the Griffon, which is more gregarious than other vultures and already numerically dominant (Cortes et al. 2010). The smaller feeding sites could be preferable for biodiversity enhancement and other scavengers. One large feeding station in a wide area (some thousands of square kilometres) could be sufficient to ensure the collection of information takes place: reading of rings (preferably automated), captures for banding, etc.

\section{Constraints of stewardship}

The discontinuation of State funding to remove carcasses does not change the technical objectives (i.e. carcasses need removal), but it changed the organisation of the system and its financing as described by Choisy (2004b). Some level of cooperation can be found with private contractors, to provide assistance with transporting dead animals, but some 
contractors can become concerned at increasing costs and are not interested in collecting carrion in remote areas. Others are concerned about competition. At the level of environmental policy, this is like opposing the development of pollution control techniques so that the operation of wastewater treatment plants can continue.

The management of a small feeding site is a very small cost compared to the benefits it brings. However, farmers may now perceive it as excessive since they are already contributing to financing industrial carcass disposal through a 'mandatory voluntary contribution'! However, this contribution can be reduced by $60 \%$ if the farmer chooses to manage a small feeding site. Regardless, little has been planned to finance or monitor small feeding sites, or deal with the removal of carcass remains, and still less to implement monitoring. To date, the regional parks and vulture associations have as their operating resources the tax per tonne from carcasses taken to the main feeding stations. The development of smaller feeding sites would lessen their resources but not their mission. The consequences of this can be pronounced in different regions:

- In the Causses (Tarn, Lozère, Aveyron), the charge per tonne for the collection of carcasses is still enough to cover operating costs, but the system is financially fragile

- In the Drôme, because of a fee of approximately half as much, the development of small feeding sites could challenge the sustainability of the larger feeding stations.

In general, the costs of collecting carcasses in the pre-Alps are compensated by lower costs in the plains and hills of the region. This draws attention to the impracticalities of a 
uniform costs per tonne across all regions.

\section{Exceptional losses of livestock}

Case studies have shown that leaving

vultures to do their job may very well be a realistic option in cases of large numbers of deaths from lightning strikes or otherwise: in the massif Central (38 sheep in the Causses), in the Alps (more) in the Pyrenees (300 in the Ossau Valley), to mention only a few examples.

Such accidents can occur during the summer, and if the department of veterinary services is on holiday, then nobody dares to make a decision and let the vultures work. Therefore, in July 2011, when more than 600 ewes died by falling off cliffs during a thunderstorm, the carcasses were evacuated by helicopter - this at a cost of thousands of Euros to the community, despite the influx of vultures that arrived to consume to carcasses: about 400 in the last case (Couloumy, Parc National des Ecrins, personal communication).

\section{Adjustment of the population according to resources}

As a population of vultures grows towards the capacity of its environment, which is largely a function of available carcasses, productivity declines slowly. It is this process that should be managed carefully. The rapid closing of large numbers of major feeding stations in some autonomous communities of Spain was responsible for depriving large numbers of scavengers of food. The consequences for the local populations of vultures were dramatic, particularly for their reproduction. Various reasons for this were:

- Technical: industrial farming from livestock such as pigs developed complicated legal situations for the 
disposal of carcasses, leading to some very questionable local situations;

- Economic: private pressure groups saw the reduction of feeding stations as an opportunity to create and develop a market for their own benefit

- Political: some autonomous communities have exploited these measures to demonstrate their freedom of action in relation to the central Government

The political decision to reduce the amount of carcasses available to scavengers was not good for vultures. However, without going into excessive detail, such brutality of management can be cited as an example of how not to proceed. By taking even the slightest concern for biodiversity and the functioning of vulture populations, it is necessary to ensure that any significant reduction in food resources is spread out over many years.

\section{Better than economic repercussions: the} synergy of policies

The benefits for farming, tourism and the environment of the return of vultures and the restoration of their populations have been, to date, that of beneficial repercussions in favour of biodiversity. We can and must now go beyond.

\section{In Asia and Africa}

Such synergy would be particularly necessary because:

- The restoration of large wildlife populations is an asset for tourism development and a major source of foreign exchange for many countries of the South; 
- The contribution of vultures to the quality the environment will always be much less costly than if it was achieved by others means. If environmental concerns are not exclusive to wealthy countries, minimising their costs to poorer countries is more relevant than anywhere else.

The preventative role of vultures for thousands of years has never been questioned, but it has been shown only recently the adverse effects on public health when their populations collapse (Markandya et al. 2006, 2008).

In Asia, greater awareness of vultures and the reasons for their declines has enabled the adoption of action plans for their restoration (Ministry of Environment Forests, Government of India 2006, Virani et al. 2001, Murn et al. 2008, Government of Nepal 2009). The replacement of the antiinflammatory lethal to vultures by one that is harmless seems possible (Swarup et al. 2007, Cuthbert et al. 2007, 2011).

In South-East Asia, the almost complete disappearance of vultures occurred many years ago, with the exception of a few residual populations in Cambodia, where their restoration has begun (Wildlife Cambodia, Birdlife International, conservation 2005).

Elsewhere, there is almost everything still to do. Poverty and food resource issues make the conservation of vultures and populations of other large animals difficult.

\section{In Europe: studies in regulation}

The integrated biogeographic and demographic restoration of the four vultures of Europe for each concerned policy, and not a biodiversity policy, still remains a pious hope, more than thirty years after the first successful reintroduction. 
However, more than just a financial contribution to the reintroduction projects of vultures, it is perhaps more valuable to seek political will in favour of the return of vultures, and their role in natural disposal of carcasses. Various studies in the Causses (see above) have shown the impact of the return of vultures on local tourism (Quillard 1995) and for the natural disposal of carcasses (Briquet 1990, Chassagne 1998). More recently, in work that combines different perspectives, there is interest in the convergence between the conservation of scavenging raptors, the minimisation of costs, and strengthening the link between agricultural and the environment (Boumellassa 2009). This is important as some issues faced by the science of conservation often include dimensions from social perspectives (Dupont 2011).

Such studies are still lacking in the Alps and the Pyrénées, and where the perspective of such work is general, it is not always possible to transfer conclusions between regions: farming methods are different, with or without carcasses being left for vultures, numbers of wild ungulates are very different, with or without chamois or ibex, etc.

The recent regulation $\mathrm{N}^{\circ}$ $142 / 2011 /$ EC now allows now that livestock carcasses can be made available to avian and mammalian scavengers. Further regulations should follow after 2012. It will "only" remain to change the procedures and practices of relevant individuals, groups and authorities.

\section{Concluding remarks}

It sometimes happens that, particularly in the Alps, enthusiasm shown by farmers for the restoration of vultures is met with indifference. Requests for the installation of local feeding sites can be refused, yet there is no reaction from the public 
organisations supposed to be concerned with them.

Too often, successful local reintroductions are considered as achieved targets, rather than a first milestone within the framework of a strategy for restoration on a continental scale. The conservation and restoration of some species is in conflict with economic interests of livestock keeprs and crop growers. This leads to sometimes successful, sometimes questionable compromises. However, considering the benefits of vultures to each concerned sector, such a timorous and narrowminded outlook cannot be accepted.

For whatever reason, whenever parks or other concerned public organisations display a lack of reflection and a passive approach, they are betraying the spirit of their mission to implement biodiversity and environmental policies.
This is a fortiori the case for associations whose commitment is supposed to be to the benefit of fauna restoration.

The idea of convergence evoked by Boumellassa (2009), if still far frombeing a reality, is at least feasible: knowledge, as an ad hoc regulatory tool exists. However, in the end implementation will depend on the political will, which alone can lead to the realisation of the goals set out in Table 2 . Of course one may wonder why, in the areas where vultures are breeding, and decision-makers fail to take an interest in the restoration of biodiversity, they are not better informed about the benefits of the return of vultures for environmental, tourism and agricultural reasons. In the public organisations and/or associations concerned, it is the responsibility of motivated individuals to convince policymakers of the relevance of such benefits. 


\section{Acknowledgements}

Reports and/or the answers to my emails from my fellow "vautoureux" have provided valuable information. My special thanks go to: Mr. Gallardo (the Luberon PNR), S. Henriquet (LPO), E. Kobierzycki (LPO), P. Lécuyer (LPO), E. Marlé (Aster), R. Néouze (LPO), P. Orabi (LPO), C. Ponchon (CEN PACA), Mr. Prouveur (PNR du Vercors), Mr. Razin (LPO), C. Tessier and J. Traversier (Vautours-en-Baronnies). My thanks also go to all the others, in particular those that provide the material: field data.

\section{REFERENCES}

Anderson M.D., 2002. The Asian vulture crisis. Could it happen in Africa? Africa Birds and Birding 5: 50-53.

Anderson M.D., Benson P., 2003. Veterinary drug implicated in vulture crash. Africa Birds and Birding 8: 12.

Anderson M.D., Mundy P.J., 2001. The demise of vultures in southern Asia: mortality factors and a risk to African vultures. South African Journal of Science 97: 342-344.

Anderson M.D., Piper S.E., Swan G.E., 2005. Non-steroidal anti-inflammatory drug use in South Africa and possible effects on vultures. South African Journal of Science 101: 112-114.

Bamford A.J., Diekmann M., Monadjem A., Mendelsohn J., 2007. Ranging behaviour of Cape Vultures Gyps coprotheres from an endangered population in Namibia. Bird Conservation International 17: 331-339.

Becker N., Choresh Y., Bahat O., 2010. Cost benefit analysis of the conservation effort to preserve an endangered species: the Griffon Vulture (Gyps fulvus) in Israel. Journal of Bioeconomics 12: 55-70.

BirdLife International 2008. Gyps coprotheres. IUCN 2011. IUCN Red List of Threatened Species. Version 2011.1 www.iucnredlist.org.

Blondel J., 1969. Synécologie des passereaux residents et migrateurs dans un échantillon de la region méditerranéenne française. Thèse de doctorat d'État, faculté des sciences, 
université de Dijon, 240 p. Édition du Centre régional de documentation pédagogique, Marseille.

Boumellassa H., 2009. Rapaces nécrophages: concilier conservation de l'espèce et minimisation des dépenses, vers un renforcement du lien agricultureenvironnement. Mémoire de DEA en économie et mathématiques, Université Paris X-Nanterre, $131 \mathrm{p}$.

Briquet R., 1990. Évaluation du rôle épidémiologique du vautour fauve (Gyps fulvus) dans le cadre de sa réintroduction en France sur les Grands Causses. Thèse de doctorat vétérinaire, faculté de médecine, Créteil, $125 \mathrm{p}$.

Camiña A., 2008. Las energía renovables y la conservación de aves carroñeras: el caso del buitre leonado (Gyps fulvus) en el Norte de la Península Ibérica. In: Mayol J., Viada C. (Eds), El rumbo del arca. Congreso técnico de conservación de fauna y flora silvestres, 26-28 Oct. 2006, Formentor, Mallorca. Conselleria de Medi Ambient del Govern de les Illes Balears, 171-180.

Chassagne M., 1998. Les vautours, équarisseurs naturels des grands Causses. Thèse de doctorat vétérinaire. École Nationale Vétérinaire de Lyon.

Choisy J.P., 2003. Réintroductions animales et biodiversité. Objectifs, stratégies. La Fayolle, revue d'information du Parc naturel régional du Vercors, 5, 18-31.

Choisy J.P., 2004 a. La réintroduction des vautours, objectifs, retombées. Document du Parc naturel régional du Vercors, $4 \mathrm{p}$.

Choisy J.P., 2004 b. Vautours et élevage extensif. Document du Parc naturel regional du Vercors, $8 \mathrm{p}$.

Cortés-Avizanda , Carrete M., Donazar J.A., 2010. Managing supplementary feeding for avian scavengers. Guidelines for optimal design using ecological criteria. Biological Conservation 143: 1705-1715.

Cramp S., Simmons K.E.L, Gillmor R., Hollom P.A.D., Hudson R., Nicholson E.M., 1980. Handbook of the birds of Europe, the Middle East and North Africa. The birds of Western Palearctic. Vol. Il., Hawk to Bustards. Oxford University Press, Oxford. pp 58-64.

Cuthbert R., Dave R., Chakraborty S.S., Kumar S., Prakash S., Ranade S.P., 2011. Assessing the ongoing threat from veterinary non-steroidal anti-inflammatory drugs to critically endangered Gyps vultures in India. Oryx 45: 420-426. 
Cuthbert R., Parry-Jones J., Green R.E., Pain D.J., 2007. NSAIDs and scavenging birds: potential impacts beyond Asia's critically endangered vultures. Biology letters 3: 1 .

Dupont H., 2011. Modélisation multi-agents d'un service. Scénario de systèmes d'équarrissage par des rapaces nécrophages. Thèse de l'École normale supérieure, 308 p., http://hal.archives-ouvertes.fr/docs/00/59/85/63/PDF/Dupont_MS2011.pdf

del Moral J.C., 2009. The Griffon Vulture: breeding population in 2008 and census method. Seguimiento de aves 30: 1-214.

Eliotout B., 2007. Le vautour fauve. Description, évolution, reproduction, observation, protection. Delachaux et Niestlé, $192 \mathrm{p}$.

Green R.E., Taggart M.A., Das D., Pain D.J., Sashi Kumar C., Cunningham A.A, 2006. Collapse of Asian vulture populations: risk of mortality from residues of the veterinary drug diclofenac in carcasses of treated cattle. Journal of Applied Ecology 43: 949-956.

Government of Nepal, Ministry of Forest and Soil Conservation, 2009. Vulture Conservation Action Plan for Nepal 2009-2013. Report 27, Department of National Parks and Wildlife Conservation.

Hirzel A., Posse B., Oggier P.A., Crettenand Y., Glenz C., Arlettaz R., 2004. Ecological requirements of reintroduced species and the implications for release policy: the case of the bearded vulture. Journal of Applied Ecology 41: 1103-1116.

Le Gouar P., Robert A., Choisy J.P. Henriquet S., Lécuyer P., Tessier C., Sarrazin F., 2008. Roles of survival and dispersal in reintroduction success of Griffon Vulture (Gyps fulvus). Ecological Applications 18: 859-872.

Markandya A., Taylor T., Longo A., Murty M.N., Murty S., Dhavala K., 2006. Counting the cost of vulture decline - economic appraisal of benefits of the Gyps vulture in India. Environmental and resource economists IIIrd World, www.sovon.nl/pdf/MPRA_paper_1692.pdf.

Markandya A., Taylor T., Longo A., Murty M., Murty S., Dhavala K., 2008. Counting the cost of vulture declines. An appraisal of the human health and other benefits of vultures in India. Ecological economics 67: 194-204.

Ministry of Environment and Forests, Government of India, 2006. Action Plan for vulture conservation in India, 28 p. 
Morio S., 2006. Évaluation des ressources trophiques disponibles pour la colonie de vautours fauves des Grands Causses. Master Gestion de la biodiversité, université Paul-Sabatier, Toulouse, $39 \mathrm{p}$.

Mundy P., Butchart D., Ledger J., Piper S., 1992. The Vultures of Africa. Academic Press, London, $460 \mathrm{p}$.

Murn, C. Khan, U. \& Farid, F. 2008. Vulture populations in Pakistan and the Gyps vulture Restoration project. Vulture News 58: $35-43$.

Naidoo V., Wolter, K., Cuthbert R., Duncan N., 2009 a. Veterinary diclofenac threatens Africa's endangered vulture species. Regulatory Toxicology and Pharmacology 53: 205-208.

Naidoo, V., Wolter, K., Cromarty D., Diekmann M., Duncan N., 2009. Toxicity of nonsteroidal anti-inflammatory drugs to Gyps vultures: a new threat from ketoprofen. Biology letters 6: 339-341.

Orabi P., 2011. Argumentaire et plan d'actions pour la Conservation du vautour fauve en France. Ligue pour la protection des oiseaux http://rapaces.Ipo.fr/mission-rapaces/argumentaireet-plan-dactions-en-faveur-duvautour-fauve

Prakash V., Pain D.J., Cunningham A.A., Donald P.F., Prakash N., 2002. Catastrophic collapse of Indian white-backed Gyps bengalensis and long-billed Gyps indicus vulture populations. Biological conservation 109: 381-390.

Prakash V., Green R.E., Rahmani A.R., Pain D.J., Virani M.Z., Khan A.A., 2005. Evidence to support that diclofenac caused catastrophic vulture population decline. Current Science 88: 1533-1534.

Prakash V., Green R.E., Pain D.J., Ranade S.P., Saravanan S., 2007. Recent changes in populations of resident Gyps vultures in India. Journal of the Bombay Natural History Society 104: 129-135.

Quillard V., 1995. Conservation de la nature, valeur sociale et économique de la biodiversité in situ. L'exemple de la réintroduction du vautour fauve (Gyps fulvus fulvus) dans les Grands Causses. Rapport de maîtrise S. et T. en aménagement et mise en valeur des régions. Université de Rennes, FIR.

Robles Marín B., 2008. Estimaciones económicas, energéticas y ambientales de la incineración de rumiantes. Contribución de las aves necrófagas al ahorro energético. 
Asociación para la Defensa de la Naturaleza Caralluma. Communication non publiée à la Conférence nationale sur les vautours en Espagne, Caravaca de la Curz (Murcia). Robles Marín B., 2010. Buitres, esos grandes aliados del medio ambiante. Quercus, 293, 80-81.

Sarrazin F., Bagnolini C., Pinna J.L., Danchin E., Clobert J., 1994. High survival estimates of Griffon Vulture (Gyps fulvus fulvus) in a reintroduced population. The Auk 111: 853-862.

Schaub M., Zink R., Beissmann H., Sarrazin F., Arlettaz R., 2009. When to end releases in reintroduction programmes: demographic rates and population viability analysis of bearded vultures in the Alps. Journal of Applied Ecology 46: 92-100.

Secretariat Against the Illegal Use of Poison, 2010. Stop poison in Europe. Impact of wildlife poisoning in Europe. European Vulture Conservation Foundation (VCF), 15 p.

Simmons R., Anderson M. D. 2007. Vulture research in East Africa. Africa Birds and Birding 12: 3 - 5 .

Sinclair A.R.E., Northon-Griffiths M., 1979. Serengeti: dynamics of an ecosystem. University of Chicago Press, Chicago, 397 p.

Slotta-Bachmayr L., Bögel R., Camina-Cardenal A. 2005. The Eurasian Griffon Vulture (Gyps fulvus) in Europe and the Mediterranean. EGVWG, Salzburg, 100 p., http://www.scribd.com/doc/20865096/Camina-2005-con-Boegel-y-SlottaBachmayr-Action-plan-Griffon-vulture-EGVWG.

Swan G.E., Cuthbert R, Quevedo M., Green R.E., Pain D.J., Bartels P., Cunningham A.A., 2006. Toxicity of diclofenac to Gyps vultures. Biology letters, 2, 279-282.

Swan G., Naidoo V., Cuthbert R., Green R.E., Pain D.J., Swarup D., Prakash V., 2006. Removing the threat of diclofenac to critically endangered Asian vultures. PLoS Biology 4: 396-402.

Swarup D., Patra R. C., Prakash V., Cuthbert R., Das D., Avari P., 2007. Safety of meloxicam to critically endangered Gyps vultures and other scavenging birds in India. Animal Conservation 10: 192-198.

Terrasse J.F., 2001. Le gypaète barbu. Description, moeurs, observation, mythologie. Delachaux et Niestlé, 208 p.

Terrasse M., Sarrazin F., Choisy J.F., Clemente C., Henriquet S., Lecuyer P., Pinna J.L., Tessier C., 2004. A success story: the reintroduction of griffon Gyps fulvus and black 
Aegypius monachus vultures in France. Proceedings of the VIth World Conference on birds of prey and owls, Budapest (Hungary). In : Chancellor R.D., Meyburg B.U. (Eds), Raptors Worldwide, WWGBP- MME (Birdlife Hungary), 127-145.

Thiollay J.M., 2006a. Large bird declines with increasing human pressure in savanna woodlands (Burkina Faso). Biodiversity and Conservation 15: 2085-2108.

Thiollay J.M., 2006b. Severe decline of large birds in the Northern Sahel of West Africa: a long-term assessment. Bird Conservation International 16: 353-365.

Thiollay J.M., 2006c. The decline of raptors in West Africa: long-term assessment and the role of protected areas. Ibis 148: 240-254.

Turnbull P.C.B., Diekmann M., Kilian J.W., Versfeld W., Devos V., Arntzen L., 2008. Naturally acquired antibodies to Bacillus anthracis protective antigen in vultures of southern Africa. Onderstepoort Journal of Veterinary Research 75: 95-102.

Virani M., Gilbert M., Watson R., Oaks L., Benson P., Khan A.A., Baral H.S., 2001. Asian vulture crisis project: field results from Pakistan and Nepal for the 2000-2001 field season. In : Katzner T., Parry- Jones J. (Eds), Reports from the Workshop on Indian Gyps vultures. Estación Biologica Donaña-Raptor Research Foundation, Seville, Spain, 7-9.

Vulture Conservation Foundation, 2002. Action plan for the recovery and conservation of vultures on the Balkan Peninsula and adjacent regions, http://www.balkanvultures.net/ActionPlan/

Wildlife Conservation Cambodia, Birdlife International in Indochina, Worldwild Fund for Nature, 2005. Cambodia Vulture Conservation Action Plan, http://naris.science.go.kr, $28 \mathrm{p}$. 